\title{
大規模病院におけるエネルギー RESEARCH ON ENERGY AND WATER と水の消費量に関する調査研究 CONSUMPTION AT LARGE-SCALE HOSPITAL
}

高草木 明—— $* 1$ 吉野大輔 — $* 2$

キーワード :

病院, 電気消費量, ガス消費量, 水消費量

Keywords:

Hospital, Electricity consumption, Gas consumption, Water consumption

\author{
Akira TAKAKUSAGI - * $* 1$ Daisuke YOSHINO $-* 2$
}

The maintenance records at a certain large-scale hospital, the total floor area $75,311 \mathrm{~m}^{2}$ hospital building and $12,793 \mathrm{~m}^{2}$ health checkup center, are investigated. The monthly and daily data of electricity, gas and water consumption are obtained. The paper presents the features of the hospital and the outline of the buildings at first, and then annual or monthly electricity and gas consumption, including CGS operation results, and water consumption are analyzed. Then, using the daily data, the correlation between the energy consumption and the enthalpy of outside air, the difference of the data on holidays, and the annual characteristics of energy and water consumption at weekdays are presented. The paper also shows the daily maximum electric power and the restraint $\mathrm{kW}$-value for the electricity demand management.

\section{1. はじめに}

大規模病院のエネルギーと水の消費量は平均的な事務所建物など に比べ著しく大きいことが知られており、建築における低炭素化を 検討するうえで無視できない。実態把握が必要である。

病院のエネルギーと水の消費量に関しては大学病院での調査結果 などが報告されているが、未だ事例数は少ない。特に長期間にわた る調査データが少ない。

著者らは病床数 556 床の大規模総合病院の保全記録を調査した。 この保全記録の中の電気、ガス、水の消費量の記録データにより、 これらの消費特性を把握することを研究の目的とする。

先ず、月次・年次の消費量を分析対象とする。事務所ビルにおけ る同様のエネルギー・水消費量調査結果との比較も加えている。次 に、日々の消費量データを分析対象とする。

病院におけるエネルギー・水消費量は、個々の病院の診療科構成 などの条件により大きな相違がある。従って、多数の病院について の調查から平均により原単位を求める調查だけでなく、1件といえ ども対象病院の成り立ちを明かしたうえでの長期に及ぶ調査結果も、 また一方の意義があると思われる。これが本技術報告の趣旨である。

本報告の調查結果は、今後の病院の計画や管理等にベンチマーク を提供するものと考えられる。

\section{2. 調査対象概要}

病院の敷地内には病院棟、健康センター棟、看護師寮 3 棟がある。 病院棟建物概要を表 1 に、同階別用途概要を表 2 に、健康センター 棟の概要を表 3 に示す。

この病院における電気、ガスの消費量は 2003 年度以降、水消費量 は 2002 年度以降の月別消費量の記録が残されている。また、電気、 ガス、水の日々の消費量が 2005 年 6 月 1 日以来記録されている。本 技術報告ではこの月次のデータと日々のデータとを使用した。
表 1 病院棟建物概要

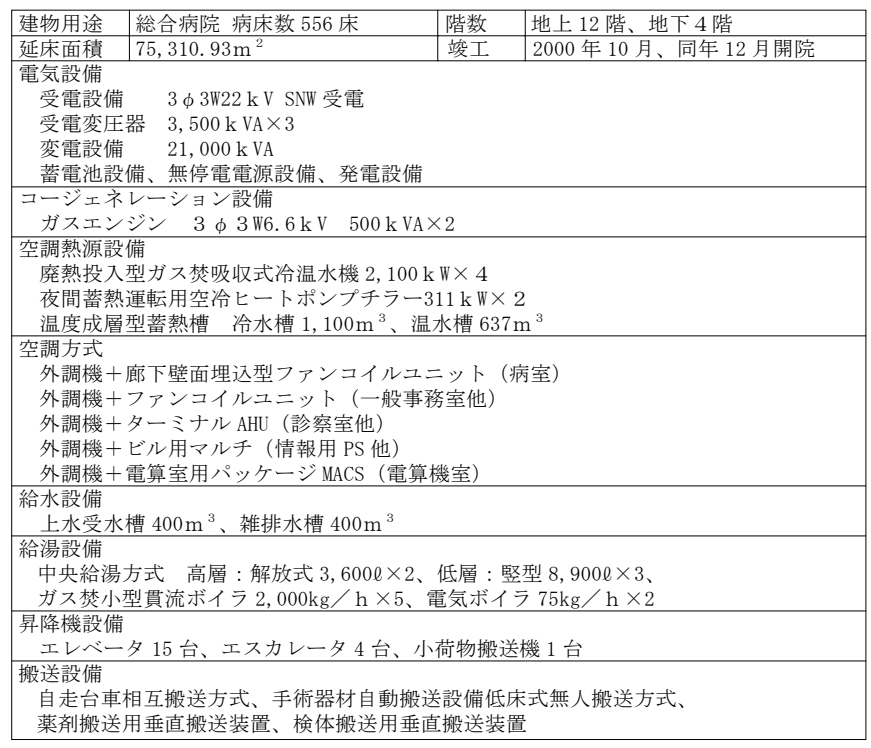

表 2 病院棟階別用途概要

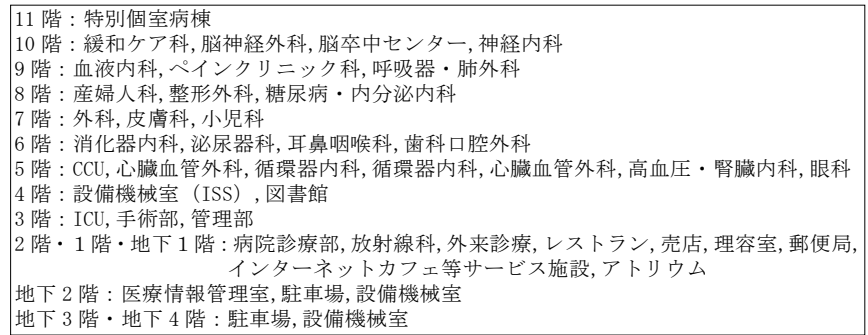

なお、病院棟には、レストラン、売店、郵便局などが営業してい るが、これらのエネルギー、水消費量は年間原単位（図 2 , 図 11 , 表 4）以外では省いている。

\footnotetext{
東洋大学理工学部建築学科 教授・博士 (工学)

（干 350-8585 埼玉県川越市鯨井 2100)
}

東洋大学工学研究科 博士前期課程
Prof., Dept. of Architecture, Faculty of Science and Engineering, Toyo Univ., Dr.
Eng.
Graduate Student, Dept. of Architecture, Faculty of Science and Engineering, Toyo Univ. 
表 3 健康センター棟概要

\begin{tabular}{|l|l|}
\hline 1972 & 年 3 月竣工, 2002 年 10 月改修完成に \\
\hline
\end{tabular}

より健康センター棟として使用 6 階 : 健康管理センター事務室

延床面積 : $12,793 \mathrm{~m}^{2}$

電気設備: 病院棟より給電

空調設備：吸収式冷温水機 $738 \mathrm{~kW} \times 2$

蒸気ボイラ $750 \mathrm{~kg} / \mathrm{h} \times 2$

給水・給湯設備 : 受水槽 $70 \mathrm{~m}$

昇降機設備: エレベータ 3 台

5 階: 人間ドック宿泊室

FM サービスセンター
F間ドック宿泊室,
H

階 : 精神神経科

3 階.2 階. 予防医学センター(健康診断.

3 階・2 階 : 予防医学センター(健康診断・

1 階: 玄関ホール, 警備員室, 設備機械室

\section{3. 年次・月次のエネルギー消費量}

病院棟、健康センターではそれぞれ電気とガスとを使用している。 これらを 1 次エネルギー換算し 2003 年度から 2008 年度における年 間消費量の変化を図 1 に示した。電気とガスの構成比率に変化がみ られるが、総量は安定的である。

1 次エネルギー換算には、電気:9.76 [MJ/kWh]、ガス:45 [MJ/ $\mathrm{m}^{3}$ ] とした。

著者らが最近調查した 10 件の事務所ビルの原単位と比較すると 図 2 のようである。事務所ビル A は、ビル使用時間が長く、また 1 階と地下に飲食店やスーパーマーケットがテナントとして入居して いるため原単位が大きい。B ビルは情報通信系企業や医療機器メー カーがテナントとして入居し内部発熱が大きいため一般的な事務所 建物より原単位が大きい。C ビルもテナントの使用している事務機 器に特殊性があり、内部発熱が大きい。D ビル、Eビルは地域熱供給 を受けている。Fビル〜Jビルは一般的な中小ビルである。

病院棟はこれらより大きく、健康センターはほぼ一般事務所ビル 並みで、平均よりやや小さい。これらの原単位データは、各事務所 ビル、病院棟、健康センターとも 2003 年度から 2008 年度の 6 年間 の平均值を使用している。ただし、病院棟のレストラン、売店、郵 便局などのテナントのデータは 2007 年度, 2008 年度の 2 年間のデ ータによっている。

図 3 は電気、図 4 はガスの延床面積あたり月間消費量の暦年変化 を示したものである。2008 年 1 月からはガスの消費量が意図的に減 らされている。その分、電気使用量が増加している。

ガス消費量の用途別内訳を、病院棟は図 5 、健康センターは図 6 に示す。病院棟において、厨房での消費量はこの図では見えない程 度で、主に冷暖房、給湯とコージェネレーションシステム（以降、 CGS）で消費されている。健康センターでは空調と給湯にのみ使用さ れている。いずれの用途でもガス消費量が徐々に低減されてきてい る。図 7 は病院棟の CGS における発電量の暦年変化である。2008 年 1 月以降、CGS の運用を減らしている。この様にガスの消費を減らし ているのは建物管理者による経済性検討の結果によるものである。

図 8 は病院棟と健康センターでの売電消費量について、昼間の電 力と夜間電力の内訳を示したものである。総計で夜間電力が $51.3[\%]$ に達している。病院は用途の性格上、夜間にも照明、空調、 医療機器などが使用され夜間の電気使用量割合が比較的大きく、更 にこの病院棟には夜間蓄熱用のヒートポンプチラーと冷水・温水蓄 熱槽が設けられている。このため電気料金単価が低く、ガス料金が 值上がりするとガスから電気へのシフトによる経済効果が現れやす い。図 9 は、この病院における 2004 年以来のガス料金の変化である。

この病院では、現場常駐の建物管理者によりコストとリンクして 設備運用が管理され、かつきめ細かな電力デマンド管理、空調再熱 の抑制、建物使用者によるエネルギー消費の無駄の排除を目的とし た省エネルギーパトロールなどが行われている。記録によれば、2005

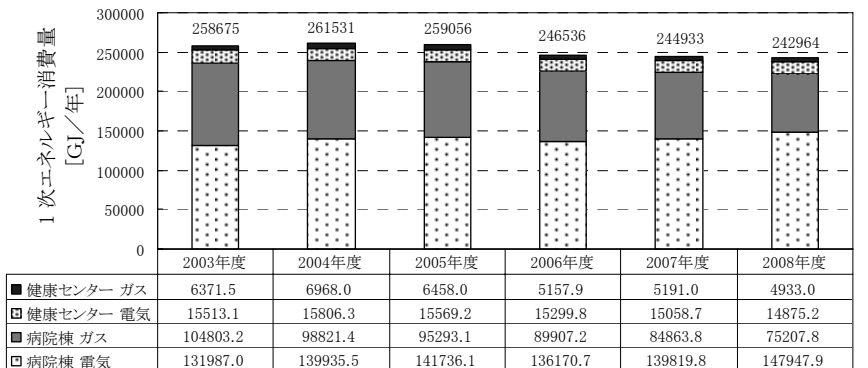

図 1 年間 1 次エネルギー消費量

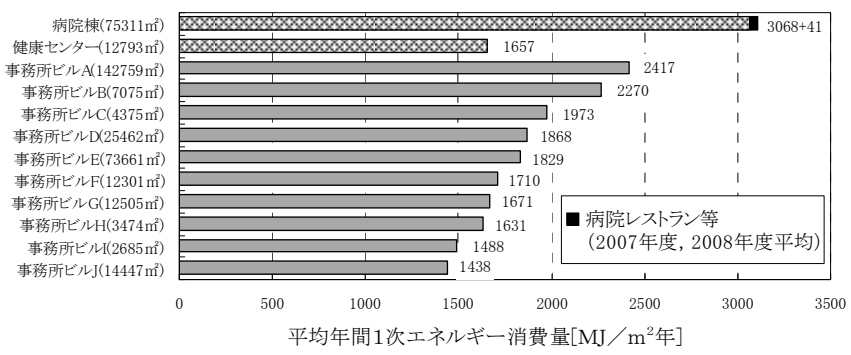

病院レストラン等以外は、いずれも 2003 年度 2008 年度の平均年間 1 次エネルギー消費量

図 2 事務所ビルとの原単位比較（1 次エネルギー）

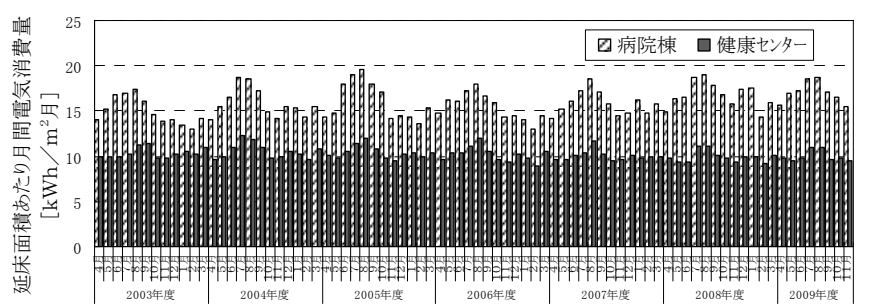

図 3 延床面積あたり月間電気消費

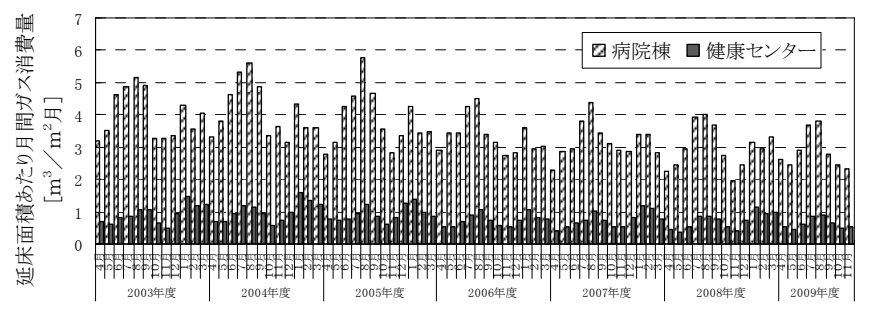

図 4 延床面積あたり月間ガス消費

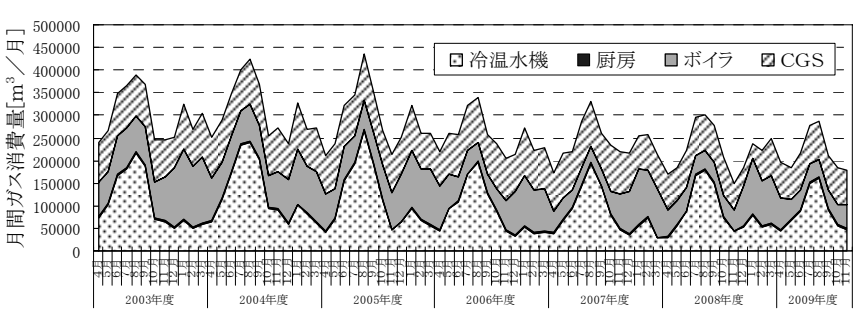

図 5 病院棟ガスの用途別月間消費量

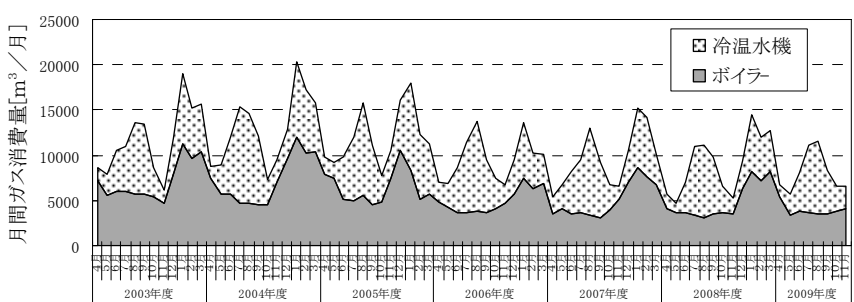

図 6 健康センター棟ガスの用途別月間消費量 


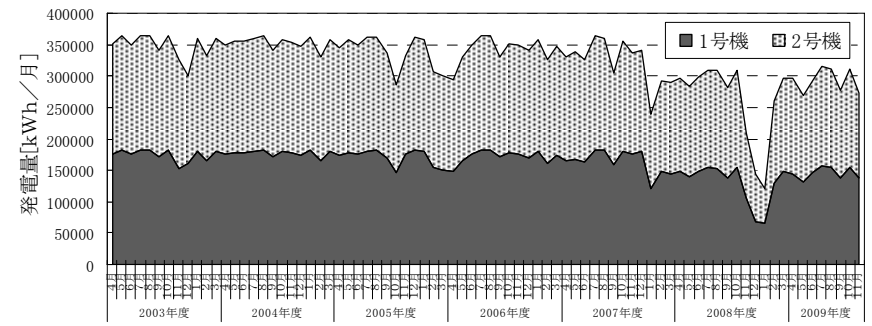

図 7 病院棟 $\mathrm{CGS}$ の発電量
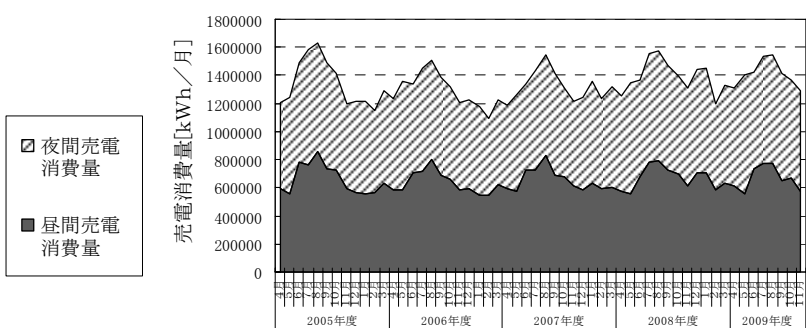

図 8 病院棟と健康センターにおける昼間売電と 夜間売電消費量（2005 年度以降）

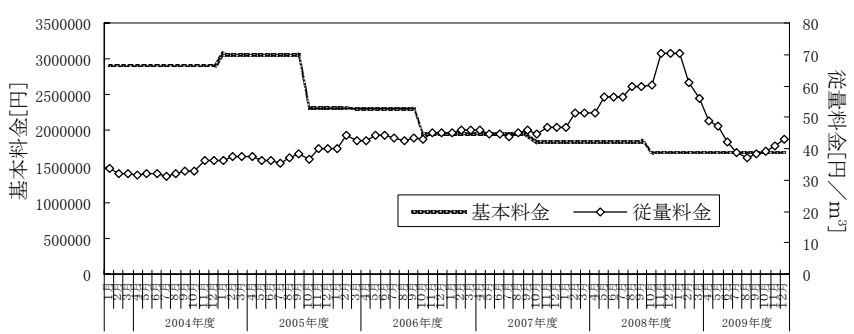

図 9 ガス料金の変化

表 4 既往研究のデータとの比較

\begin{tabular}{|c|c|c|c|c|}
\hline 年間1次エネルギー消費量 $\left[\mathrm{MJ} / \mathrm{m}^{2}\right.$ 年 $]$ & 延床面積 $\left[\mathrm{m}^{2}\right]$ & 件数(デー夕数) & 文献番号 & \begin{tabular}{|c|} 
デー夕期間 \\
\end{tabular} \\
\hline 3109 & 75310.93 & & 本調查 & 2003〜2008年度 \\
\hline 約 4000 (平均) & $50,000 \sim 120,000$ & & 1) & 1997年度 \\
\hline 4729.65 & 58424.07 & & 2) & 1997、1998年度 \\
\hline 2961(平均) & 20,000 以上 & & 3) (北海道) & 1999年度 \\
\hline 2215 (平均) & 小規模 ～大規模 & 62 & 5) (北海道) & 2000年度 \\
\hline 3340 & 34567 & & 6) & 2002、2003年度 \\
\hline 4231 & 76043 & & 7), 8) & 2004年度 \\
\hline 3632 & 約 29,000 & 1 & & \begin{tabular}{|l|}
$2003 \sim 2005$ 年度 \\
\end{tabular} \\
\hline 4144 & 約53,000 & & & 2003～2005年度 \\
\hline 3850 & 約 37,000 & 1 & 9)、10) & $2004 、 2005$ 年度 \\
\hline 4109 & 約 20,000 & 1 & & 2005 年度 \\
\hline 約 4000 & 40688 & & 11) & $2003 \sim 2005$ 年度 \\
\hline 約 4200 & 27471 & & 13) & 2006年度 \\
\hline 約 3400 (平均) & 30,000 以上 & 19 & 15) & 2006年度 \\
\hline 3393(平均) & $13,055 \sim 94,827$ & 21 & 16) & $2005 、 2006$ 年度 \\
\hline 4411 (平均) & $44,334 \sim 100,712$ & 10 & 18) & 2007 年度 \\
\hline
\end{tabular}

年以来、この病院の建物管理者は省エネルギーに重点的に取り組ん できた。その成果は 2006 年度から現れている。

年間 1 次エネルギー消費量原単位を既往調查の他の病院のデータ と比較すると表 4 のようになる。エネルギー消費量と延床面積で 「約」と付してある数字は、数值が文献中に記載されていないため グラフから読み取った值である。本調査対象の病院棟のエネルギー 消費量は他の大規模病院と比べ小さいといえる。

\section{4. 水消費量}

図 10 は延床面積あたり年間水消費量である。2004 年度のデータ には一部久落があるため除外した。エネルギー消費量と同様、2006 年度以降減っている。健康センターの水使用量のデータは 2004 年度 以前のものが無い。

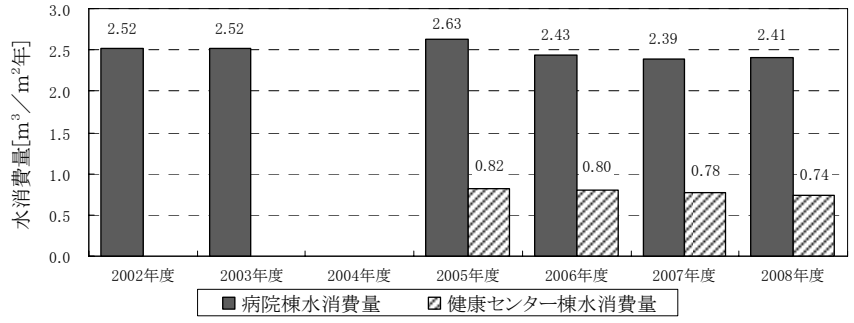

図 10 延床面積あたり年間水消費量

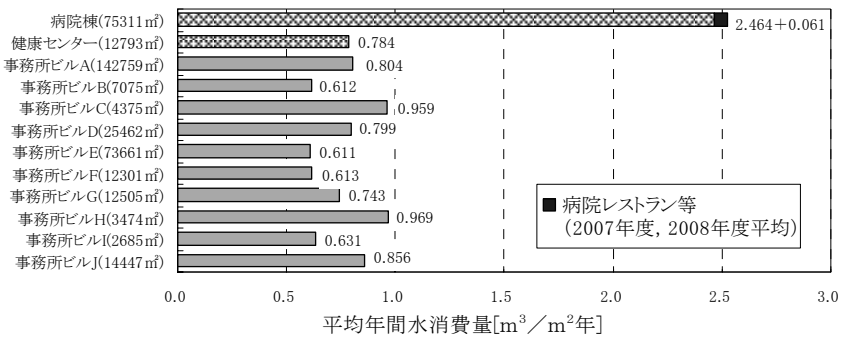

病院レストラン等以外は、いずれも 2003 年度 2008 年度の平均年間水消費量

図 11 事務所ビルとの原単位比較（水消費量）

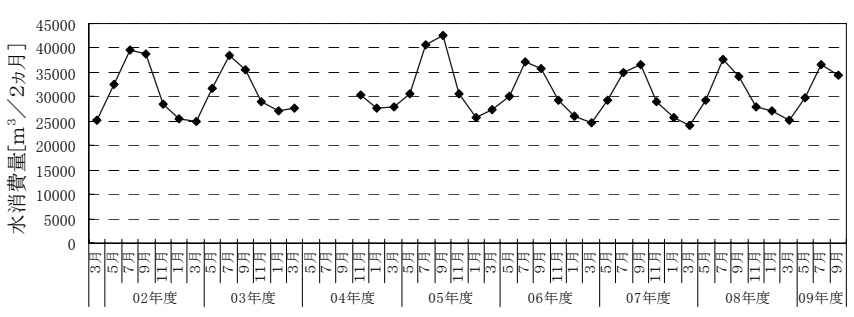

図 12 病院棟における水消費量（2力月毎）

これら平均を事務所ビルの原単位と比較すると図 11 のようにな る。健康センターは一般事務所ビルなみであるが、病院棟は著しく 原単位が大きい。

図 12 は、病院棟の 2 力月毎の水消費量の変化である。毎年 7 月、 9 月がピークとなる。

\section{5. 平日のエネルギー・水消費量と外気エンタルピ}

この病院における電気、ガス、水の日々の消費量が 2005 年 6 月 1 日以来記録されている。日々のデータの概要を表 5 に示す。土日、 祝日、年末年始（12月 29 日〜 月 3 日）は外来休診となっている。 日々の計測は毎朝 10:00 に行っている。例えば月曜の計測結果は、 ほぼ前日の日曜日の結果であるから、保全記録上は月曜のデータと なっているが本調查では 1 日ずらして日曜のデータというようにし た。

計測は保全員が行っており自動計測ではない。従って、計測時間 が若干ずれることがある。個々のデータは当日の 10:00 から翌日の $10: 00$ までの消費量である。このようにして土曜、日曜、祝日のデ 一タを除き、平日のデータとしている。計測時間の設定のため金曜 のデータには負荷の軽い土曜日の深夜から朝 10:00 までが加わるの で金曜は他の平日に比べ消費量がやや少ない。

本論文では 2009 年 9 月 17 日までのデータを分析対象とした。図 13 は、平日における電気、ガスの 1 次エネルギー消費量と保全現場 で計測された温度、湿度より計算した外気エンタルピの日変動を示 したものである。 
表 5 日々のデータの概要

\begin{tabular}{|l|}
\hline 電気消費量、ガス消費量、水消費量データ \\
\hline データ期間 $: 2005$ 年 6 月 1 日 2009 年 9 月 17 日 \\
05 年 10 月 1 日, 同 2 日のデータは電気、ガス、水とも久落 \\
電気消費量のみ 09 年 9 月 15 日のデータが久落 \\
2006 年 4 月 8 日 2005 年 8 月 20 日が異常值のため削除 \\
水消費量のみ 07 年 3 月 25 日のデータが久洛
\end{tabular}

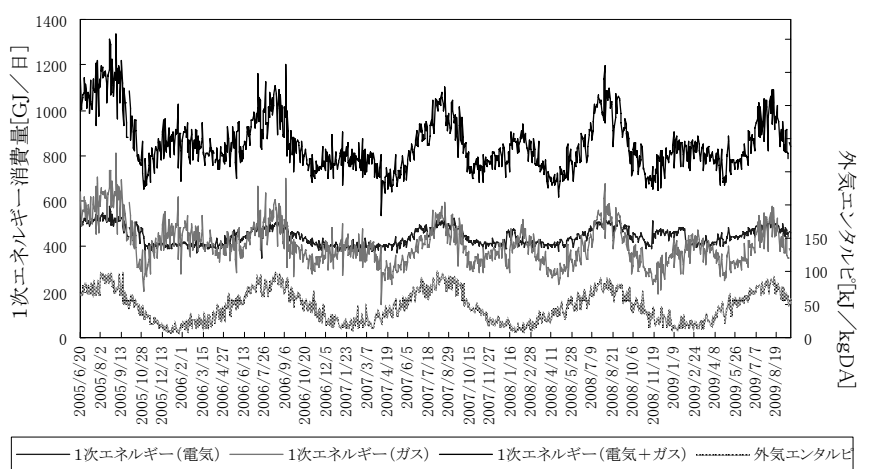

図 13 平日の電気・ガス 1 次エネルギー消費量と 外気エンタルピの日変化

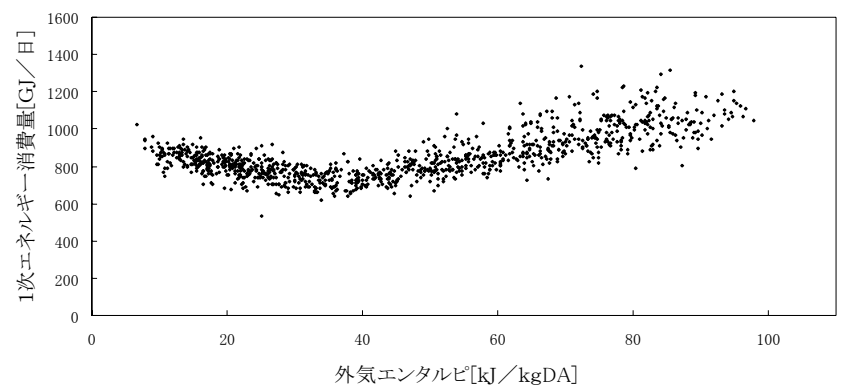

図 14 外気エンタルピと 1 次エネルギー消費量の関係

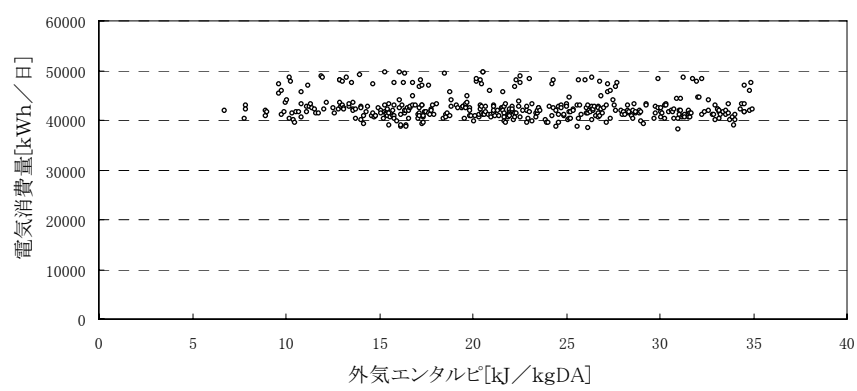

図 15 外気エンタルピと電気消費量の関係

(冬期、外気エンタルピ $35[\mathrm{~kJ} / \mathrm{kgDA}]$ 未満)

図 14 は外気エンタルピと 1 次エネルギー消費量の関係である。 電気消費量の場合、冬期は図 15 ように外気エンタルピに関わらずほ ぼ一定である。夏期は図 16 のように外気エンタルピと相関性が高い。 これは主に空調設備の運転のためである。

ガス消費量の場合、冬期は図 17 のように外気エンタルピとある程 度の相関性が認められる。これは、暖房を主にガスによっているか らである。夏期は図 18 のようになる。この相関性の高さは吸収式冷 凍機の使用のためである

水消費量は図 19 示すように冬期は外気エンタルピに関わらない が、夏期は図 20 に示すようにある程度の相関が認められる。

なお、冬期と夏期との境は図 14 において、1 次エネルギー消費量 が最も小さくなる外気エンタルピ $35[\mathrm{~kJ} / \mathrm{kgDA}]$ とした。

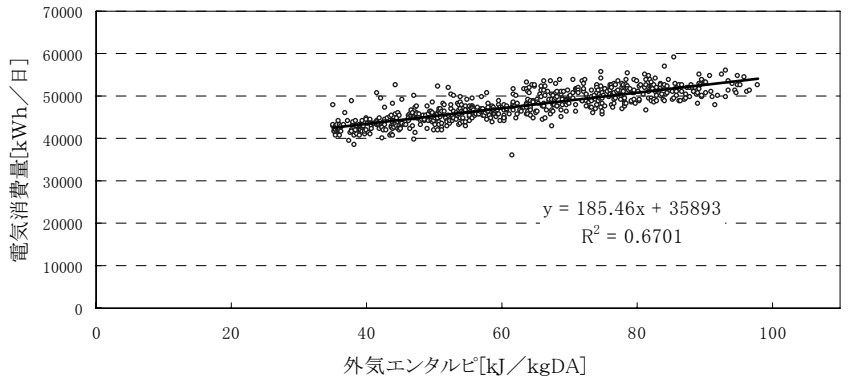

図 16 外気エンタルピと電気消費量の関係

（夏期、外気エンタルピ $35[\mathrm{~kJ} / \mathrm{kgDA}]$ 以上）

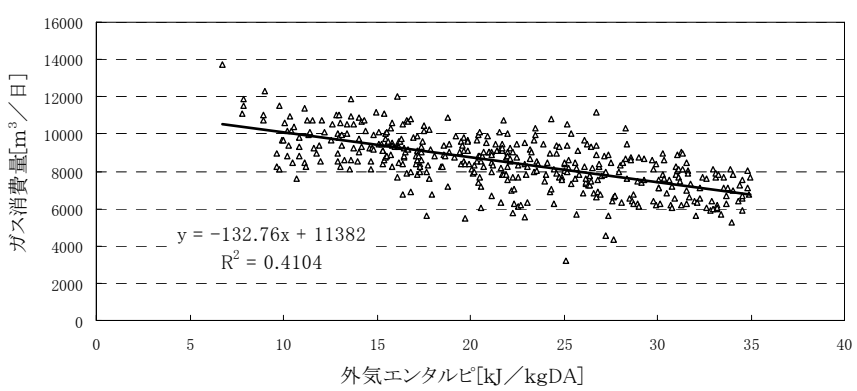

図 17 外気エンタルピとガス消費量の関係 (冬期、外気エンタルピ $35[\mathrm{~kJ} / \mathrm{kgDA}]$ 未満)

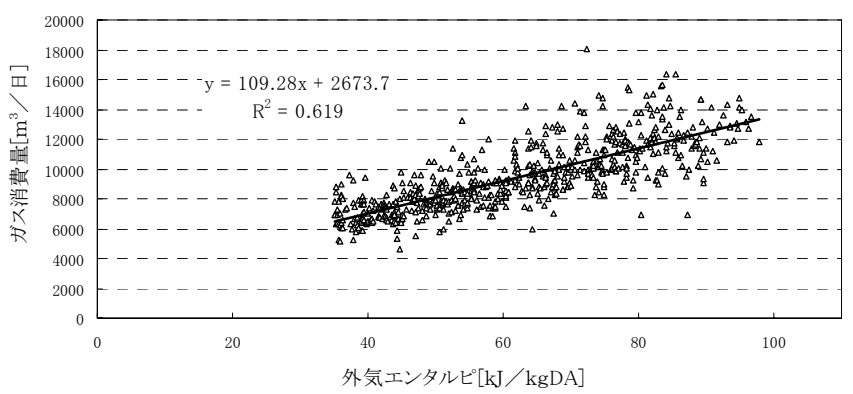

図 18 外気エンタルピとガス消費量の関係

（夏期、外気エンタルピ $35[\mathrm{~kJ} / \mathrm{kgDA}]$ 以上）

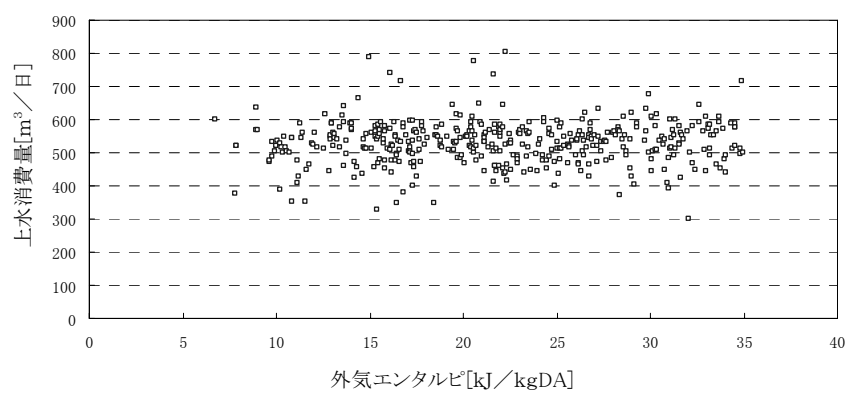

図 19 外気エンタルピと水消費量の関係

(冬期、外気エンタルピ $35[\mathrm{~kJ} / \mathrm{kgDA}]$ 未満)

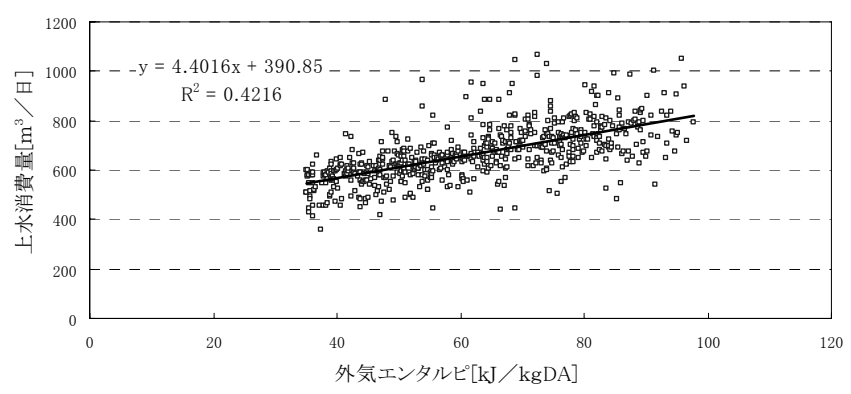

図 20 外気エンタルピと水消費量の関係

(夏期、外気エンタルピ $35[\mathrm{~kJ} / \mathrm{kgDA}$ 未満) 


\section{6. 休日（土日と祝日）のデータ}

土日、祝日は外来休診のためエネルギー消費量と水消費量とが小 さくなる。電気とガスについて冬期と夏期に分けて日平均 1 次エネ ルギーでの平日と休日の相違を示すと図 21 のようになる。休日の消 費量は平日に比べると、冬期は、電気が 85.1 [\%]、ガスが $84.2[\%]$

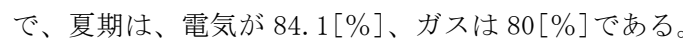

この病院は特高受電で遠隔監視装置を備えているので、日曜日に は電気料金が夜間料金の水準になる。このため、ガス料金とのか称 あいで、2008 年 1 月以降は、日曜日のガスによる CGS の運転をとり やめるなどの運用を行っており、休日のガス消費にはこの影響もあ る。

水消費量は、図 22 に示すように休日には平日に比心゙、冬期に 61.7[\%]、夏期に 66.7[\%]と顕著に小さい。

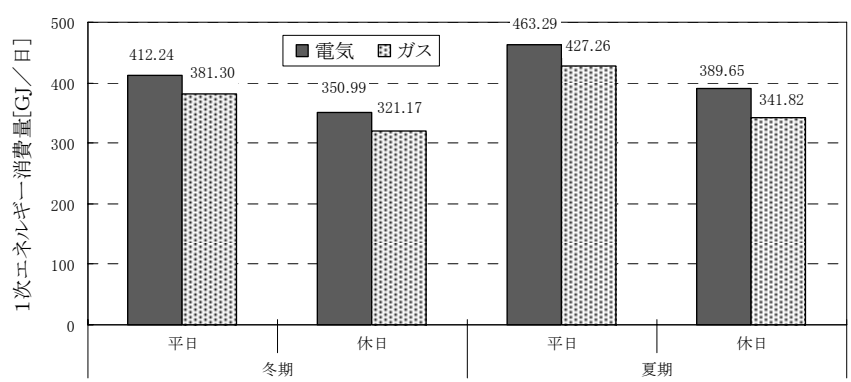

図 21 日平均 1 次エネルギー消費量

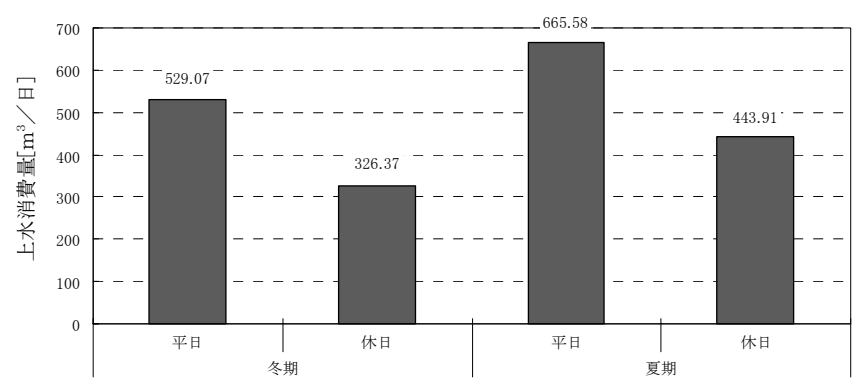

図 22 日平均上水消費量

\section{7. 日々のデータ（平日）による年間消費特性}

年間の平日の日数は 242 日〜246 日である。この日数の平日の 1 日あたりのエネルギー消費量について、2005 年 9 月から 1 年毎に累 積度数曲線によって年間の消費特性を示す。

図 23 は 1 次エネルギー消費量の年間消費特性である。2006 年 9 月〜 2009 年 8 月の 3 年間では、およそ 50 日間は 1 日に消費する 1 次エネルギーが $750[G J]$ 程度以下であり、150 日間は 750〜900[GJ] の狭い範囲にある。42〜46 日間はエネルギー消費のピークで、900 ～1200 [GJ] と広い範囲に及ぶ。省エネルギー対策の実施前の 2005 年 9 月からの 1 年間は 1 次エネルギー消費量が顕著に大きい。

図 24 は電気の年間消費特性である。2005 年 9 月からの 3 年間で は、100 日間強程度は電気消費量が狭い範囲にあるが、140日間程度 は広い範囲となり、ピークの日数は少ない。2008 年 9 月からの 1 年 間は主に $43000 \sim 47000[\mathrm{kWh}]$ の範囲で度数が減り、1 日あたり電気 消費量の平均值が大きくなっている。主に CGS の運転を減らしたこ とに伴う変化と考えられる。

図 25 はガスの場合であり、図 23 の 1 次エネルギーの場合と似た

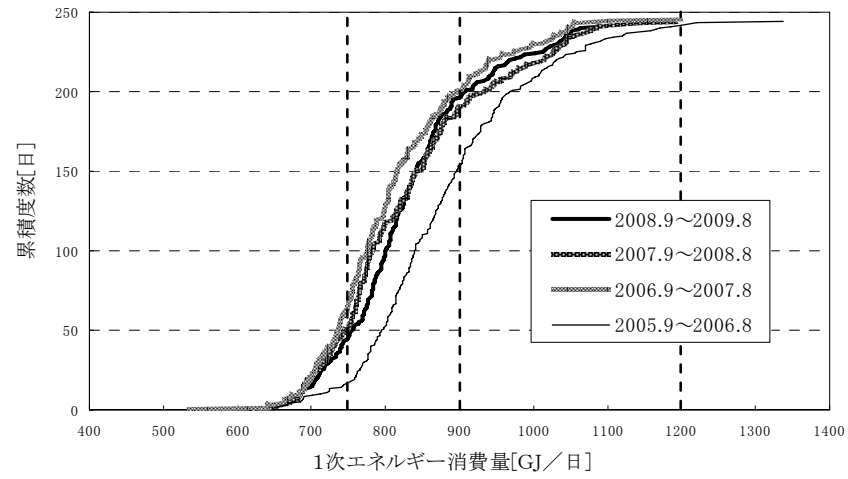

図 231 次エネルギー（電気十ガス）の年間消費特性（平日）

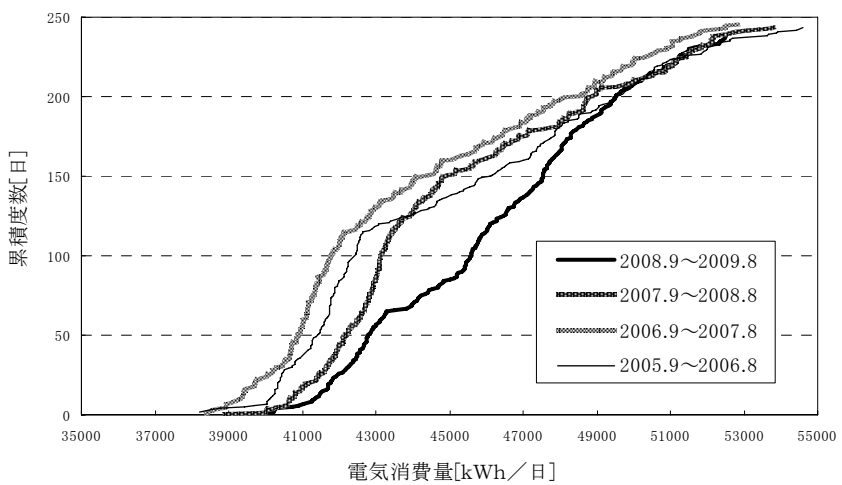

図 24 電気の年間消費特性（平日）

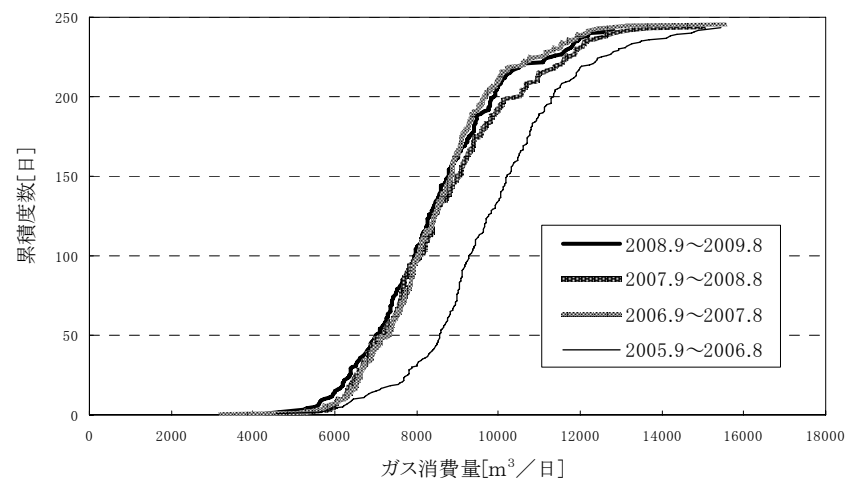

図 25 ガスの年間消費特性（平日）

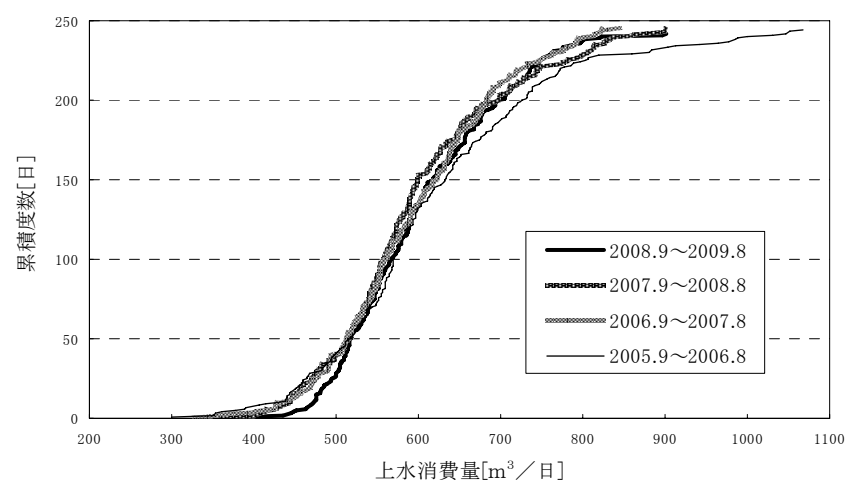

図 26 上水の年間消費特性（平日）

$\mathrm{S}$ 字型曲線を成している。

図 26 は上水の年間消費特性を示す。 2005 年 9 月からの 1 年間に は、一時的な水の過剩消費があった。節水と省エネルギー策強化の きっかけの一つとなった。以降、安定している。 


\section{8. 最大電カとデマンド制御}

調查対象病院では電力デマンド制御を自動ではなく保全員の判断 でマニュアルにより行っている。

2005 年 6 月 20 日以降、デマンド制御の記録として日最大電力と、 規制值が記録されている。図 27 は平日の電気消費量と日最大電力の 相関である。これらの相関性は高い。

図 28 はデマンド制御の規制值の度数分布である。これは 2005 年 6 月 20 日から 2009 年 9 月 17 日までの 1549 日（2 日欠測）のデータ を平日と休日に分けて示したものである。200〜250[kW]における規 制が平日、休日とも最も多い。日最大電力は平日では 2000〜 $2500[\mathrm{~kW}$ 程度が多いので、およそ 1 割程度の規制がかけられている とみられる。休日は平日と同程度の規制をかけており、休日は日最 大電力が小さいからこの割合は大きくなっている。

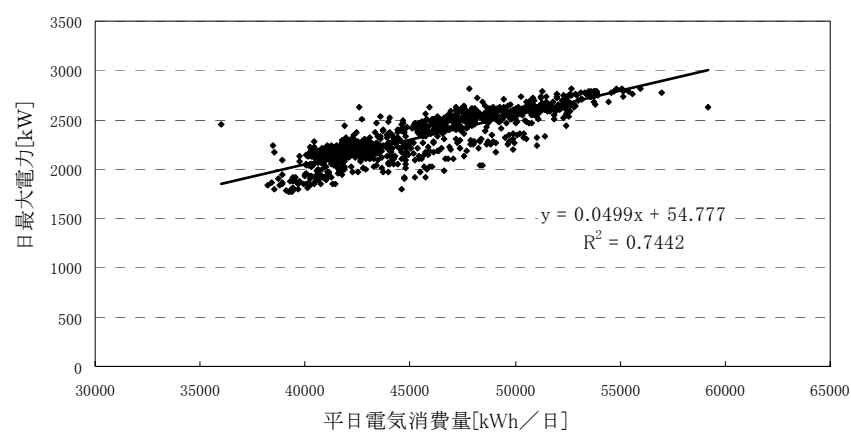

図 27 平日 1 日あたり電気消費量と日最大電力の相関

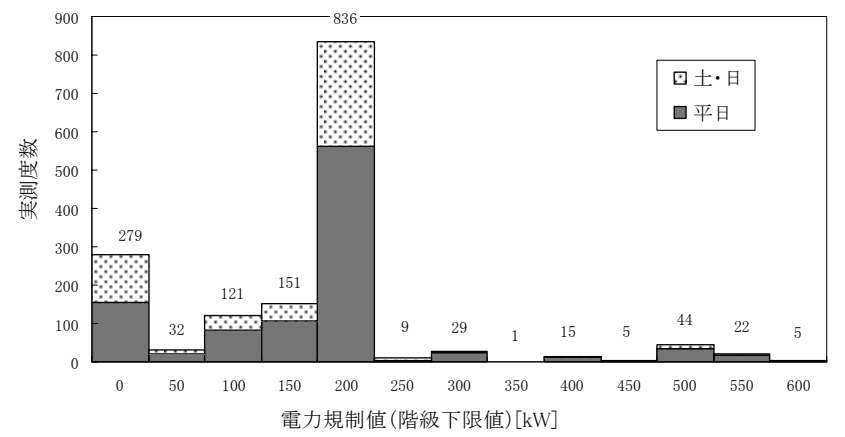

図 28 デマンド制御規制值の度数分布

\section{9. まとめ}

病床数 556 床の大規模病院の病院棟と健康センター棟についてエ ネルギーと水消費量の長期にわたる記録データを調查した。

先ず、病院の建物概要を示したうえで、年次、月次の消費量デー タにより原単位や暦年変化を示しエネルギーと水の消費特性を把握 した。原単位により事務所建物の場合と比較すると、1 次エネルギ 一消費量は、病院棟では事務所建物 10 件の平均より約 1.7 倍大きく、 健康センターでは事務所建物平均よりやや小さい。水消費量は、病 院棟では事務所建物よりはるかに大きく、健康センターでは同程度 である。1 次エネルギー、水とも長期的には減少傾向を示している。

長期にわたる電気、ガス消費量、CGS 発電量の変動状況から、ガ ス料金の変化に対応した熱源設備運用上の現場での工夫が窥える。 次に、日々のエネルギー・水消費量データを分析した。先ず、平 日の 1 日あたりのエネルギー・水消費量と外気エンタルピとの相関
性を示した。また、休日のエネルギー・水消費量について平日との 相違を示した。

平日のエネルギー・水消費量データにより 2005 年 9 月から 1 年毎 に累積度数曲線を作成し、これによって年間の消費特性を把握した。 また、電力デマンド制御における規制值の状況を示した。

\section{参考文献}

1) 三浦秀一, 須藤諭, 渡辺浩文, 吉野博: 東北地方における店舗及び病院のエネ ルギー消費に関する調査 東北地方における建築物のエネルギー消費実態 に関する調査研究 その 1, 日本建築学会東北支部研究報告集, pp. 317-322, 1999. 6

2) 松本敏男, 工藤牧子, 小島龍也: YU 病院におけるエネルギー消費量の実測調 查, 日本建築学会大会学術講演梗概集 D-2 分冊, p. 1063, 1999. 9

3) 久保田克己, 羽山広文, 森太郎, 繪内正道, 田甫英之: 北海道における病院建 物のエネルギー消費実態調査 第 1 報 札幌市における調査結果, 日本建築 学会大会学術講演梗概集 D-1 分冊, p. 591, 2001.9

4) 田甫英之, 羽山広文, 森太郎, 繪内正道, 久保田克己: 北海道における病院建 物のエネルギー消費実態調査 第 2 報 エネルギー消費特性の分析, 日本建 築学会大会学術講演梗概集 D-1 分冊, p. 593, 2001.9

5) 羽山広文, 田甫英之, 絵内正道, 森太郎: 札幌市における業務用建物のエネル ギー消費実態調査 その 1 事務所・病院・学校の調査結果, 日本建築学会大 会学術講演梗概集 D-1 分冊, p. 513, 2002.8

6) 土川紫乃文, 奥宮正哉, 田中英紀: 病院施設の運転時性能検証に関する研究 第 1 報 既設病院のエネルギー消費と熱源運転実態調査, 日本建築学会大会 学術講演梗概集 D-2 分冊, p. 1449, 2004. 8

7) 大田智紀, 浅野良晴:SU 病院におけるエネルギー消費量に関する調查研究, 日本建築学会北陸支部研究報告集, pp. 165-168, 2006.7

8) 大田智紀, 浅野良晴:SU 病院におけるエネルギー消費量に関する調查研究, 日本建築学会大会学術講演梗概集 D-2 分冊, p. 241, 2006.9

9) 玄姫, 渡辺仁人, 高偉俊: 病院のエネルギー消費量について 北九州市におけ る病院のエネルギー消費量に関する実態調査 (その 1), 日本建築学会九州支 部研究報告集, pp. 401-404, 2007.3

10) 玄姫, 高偉俊, 李海峰: 総合病院のエネルギー消費量実態 北九州市におけ る病院のエネルギー消費量に関する研究 (その1), 日本建築学会大会学術講 演梗概集 D-1 分冊, p. 853, 2007.8

11) 渡辺仁人, 玄姫, 高偉俊: 北九州市立医療センターにおけるエネルギーシ ステムの利用状況 北九州市における病院のエネルギー消費量に関する実 態調査 (その 2), 日本建築学会九州支部研究報告集, pp. 405-409, 2007. 3

12) 高偉俊, 玄姫, 李海峰: 市立医療センターのコージェネレーションシステム の運転実態 北九州市における病院のエネルギー消費量に関する研究(その 2), 日本建築学会大会学術講演梗概集 D-1 分冊, p. 855, 2007. 8

13) 黒田英男, 河村貢, 三原一伸, 山内桂一:榊原記念病院の部門別エネルギー 消費実態について (第一報: 病院全体のエネルギー消費実態の概要), 日本建 築学会大会学術講演梗概集 D-2 分冊, p. 1383, 2007.8

14) 黒田英男, 河村貢, 浅谷貴樹, 馳平心: 榊原記念病院の部門別エネルギー消 費実態について (第二報: 部門・エリア別エネルギー消費), 日本建築学会大 会学術講演梗概集 D-2 分冊, p. 1261, 2008.9

15) 三浦秀一, 吉野博, 須藤諭, 渡辺浩文, 許雷, 井城依真: 東北地方における建 物のエネルギー消費特性に関する実態調査 庁舎及び病院のエネルギー消 費量, 日本建築学会東北支部研究報告集, pp. 41-42, 2008.6

16) 朴省俊, 湯浅和博, 新谷健: 病院のエネルギー消費に関する研究 その 1 ア ンケート調査に基づくエネルギー消費量, 日本建築学会大会学術講演梗概 集 D-1 分冊, p. 805, 2009. 8

17) 新谷健, 湯浅和博, 朴省俊:病院のエネルギー消費に関する研究 その 2 エ ネルギー消費構造に関する分析, 日本建築学会大会学術講演梗概集 D-1 分 冊, p. 807, 2009. 8

18) 塙雄太, 恒川和久, 生田京子, 谷口元: 大学附属病院における施設運営費及 びエネルギー消費量に関する研究一中部地方の大学におけるケーススタデ イー, 日本建築学会大会学術講演梗概集 F-1 分冊, p. 1451, 2009. 8

[2010 年 6 月 17 日原稿受理 2010 年 7 月 30 日採用決定］ 